\title{
Explaining Torture: A Case Study
}

\author{
Claudia Reyes-Quilodran ${ }^{1, *}$ and Martha Cottam ${ }^{2}$
}

\author{
${ }^{1}$ Av. Vicuña Mackenna 4860, Santiago, Chile; ${ }^{2}$ Washington State University, USA
}

\begin{abstract}
During the late 1960s and early 1970s, most Latin American countries experienced military coups and military interventions in government affairs. One of the worst consequences of these military interventions was the torture and murder of thousands of people. This study focuses on the perpetrators of torture and examines group influences on the occurrence of torture and the behavior of torturers. To achieve this goal, we have conducted field research to interview and evaluate individuals who were members of the Chilean police and military during the 1980s. Interviews were conducted with Chilean military and police torturers active during the military regime (1973-1990). Group influences are strongly associated with the institutional context. The study identifies common patterns among the perpetrators but also considers the marked differences between them and demonstrates the important role of the group in enabling the perpetration of torture. Few studies have examined torture behavior in an institutional framework, and the identification of these features may allow this type of crime to be prevented.
\end{abstract}

Keywords: Torturer behavior, political crimes, group influences, torture.

During the late 1960s and early 1970s, most Latin American countries experienced military coups, military intervention in government affairs, and the birth of numerous military regimes (e.g. Never Again 1986; Rettig, Castillo, Cea, Jiménez, Martín, Novoa, Vial and Zalaquett 1991; Uruguay Nunca Más 1992). These military interventions severely damaged democratic institutions and affected the political and social evolution of each country. One of the worst consequences was a large volume of human rights violations, especially among vulnerable populations such as the poor and indigenous groups. Unfortunately, Chile was no exception. The military coup of 1973 established a military regime that lasted for seventeen years, from 1973 to 1990 . As a result of this military dictatorship, 1,322 people were killed and 957 people disappeared (Rettig et al.1991). In addition, approximately 27,255 people were tortured but survived (Valech, Sepúlveda, Amunátegui, Fouillioux, Gómez, Lira, Sierra, and Varela 2004). This study examines the elements that motivate people to commit torture, the cruelest violation of human rights.

The concept of torture is defined by the United Nations (1974) as any act through which severe pain or suffering, whether physical or mental, is intentionally inflicted by, or at the instigation of, a public official for purposes such as obtaining information, obtaining confessions from the victim or a third party, punishing the victim for an act he has committed, or intimidating the victim or other persons. The definition does not include pain or suffering arising only from, inherent in, or incidental to, lawful sanctions that are consistent

*Address correspondence to this author at the Pontificia Universidad Católica de Chile; Tel: (56)991287426; E-mail: claudiar@uc.cl with the Standard Minimum Rules for the Treatment of Prisoners. Torture is a systematic act that inflicts physical and psychological pain on victims who resist and is not merely an abusive relationship between two actors as suggested in other studies (Reicher and Hasmal 2006; Hasmaland and Reicher 2007). In Chile, torture is illegal, and the law punishes individuals who perpetrate this crime (Código Procedimiento Penal 1906, artículo 232; Ley 19696 2000, artículo 93). Torture is not an accidental act; it occurs in a prepared setting and requires both physical infrastructure and instruments for use against the victims. This study does not investigate guards' patterns of behavior in the prison system because torturers did not perform this function (i.e., guarding the victims). Rather, they spent a few hours with the victims in an interrogation, and they did not establish stable relationships with them. This analysis focuses on the interactions between perpetrators and victims, including the aspects that motivate an individual to torture and the explanations they offer for their behavior.

\section{BRIEF DESCRIPTION OF THE PHENOMENON AND THEORETICAL FRAMEWORK}

There are few studies of actual torturers. HaritosFatouros $(1988 ; 2003)$ conducted one of the few studies of torturer behavior using a sample of Greek soldiers who were directly involved in torture. HaritosFatouros analyzes the process that turns the normal behavior of an army recruit into the deviant behavior of a torturer at military police training camps during the period of military rule in Greece (1967-74). Based on these results, the researcher concludes that special selection procedures (including the use of recruits as young as 18) and a training process that emphasizes the authorization of violence can make anyone "a 
potential torturer." Later, Huggins, Haritos-Fatouros and Zimbardo (2002) examined a sample of twentythree Brazilian police officers - torturers and death squad murderers - who participated in a repressive military regime (1964-1985). The objective of the research was to understand the transformation of a man into a torturer and to identify the broader social and political contexts that facilitate state-sanctioned torture. In this study, the researchers found that informal daily socialization within elite police organizations was the key to perpetrating torture. Indeed, the most consistent and useful information came from other police officers in routine settings. Information passed from one perpetrator to another through oral traditions, including learning how to address the emotional repercussions of their behavior. Unfortunately, the ages of these Brazilian police recruits are not reported in the study.

Individual motivation is also relevant in the manifestation of torture. The life situations produced by sociopolitical or cultural issues and the specific scenario, coupled with socialization through experiences such as torture training, can predispose a subject's perceptions of the opponents of a regime. Perceptions of threat are accompanied by a tendency to engage in extreme stereotyping (Cottam and Cottam 2001). This is particularly true when group identity is strong and when the stereotyped opponent is equal in capability and harmful in intentions, that is, when the image comprises particular attitudes. Realistic conflicts emerge when individuals observe that they have limited status, power, and resources. Individuals perceive that they do not have what they deserve, which predisposes them toward violence (Coser 1986). This notion coincides with Staub's (1989) study of genocide and mass killing, which indicates that the drive for selfprotection motivates people to defend their physical and psychological selves against a real or perceived threat. Attitudes toward torture can be shaped by beliefs, stereotypes, and affective dispositions derived from personal interests, values and self-social interactions (Davies 1973). These elements help explain why military violence focuses on specific social groups - members of the working class, guerrilla groups or those identified as an enemy (Cottam et al. 2001; Cottam 1977; Hermann 1985; Cottam 1986; 1994). These individuals firmly believe that their opponent is a diabolical enemy determined to and capable of destroying their nation. Their strategy is typical of those associated with the enemy image: contain the enemy by preventing it from increasing its power and, in the process, try to diminish its power. Given the grave threat posed by such an enemy, no tactics are prohibited if they will save the individual from the danger posed by the enemy.

Social identity and self-categorization may also play a role in predisposing people toward torture. Strong group identification drives the development of ingroup/out-group classifications that contribute to an "us vs. them" worldview (Cottam et al. 2004; Cottam, Dietz, Mastors and Preston 2010). When a group with which they identify is threatened, people react strongly, their stereotypes of out-groups intensify, and they are motivated to use violence if necessary to preserve the in-group (Cottam and Cottam 2001). In addition, belonging to a highly cohesive group affects individual members' self-definition and self-esteem (Brown 2000).

Even though personal motivations can drive a person toward any behavior, including deviant behavior, such deviant behaviors are likely to occur in the company of others, particularly the first time (Tittle and Paternoster 2000), and group support is essential for learning how to deviate and for sustaining the behavior. Furthermore, while peer associations are particularly important for youthful deviance, they continue to affect the probability of deviance throughout a person's life (Tittle 1980; Tunnell 1993). Groups also provide social support, specifically a set of beliefs that support deviant activities and give people courage (Matza 1964). Such groups often have well-developed procedures for recruiting new members. Many deviant or criminal behaviors are at least partially organized in subcultures that feature some type of recruitment (Tittle and Paternoster 2000).

Group acceptance is important to people to the extent that it uniquely fulfills important needs. For example, a person who is a member of many groups that meet a particular need, such as companionship, is less dependent on any single one and is therefore less likely to fear rejection and less subject to group pressure. Peer influence is very powerful during adolescence because this is the transitional period between childhood (when these needs are met in close, intimate kinship groups) and adulthood. Adolescents are breaking free of childhood familial bonds but have not yet established new adult familial relationships. Hence, peer groups greatly influence young people, and the need for social acceptance becomes especially great (Tittle and Paternoster 2000: 399). A group has the ability to grant recognition, prestige, or status to its members regardless of their 
age (Kiesler and Kiesler 1969). Because individuals are generally subordinates in society, they are especially attuned to groups that can provide recognition and prestige (Tittle and Paternoster 2000: 400). Young group members often engage in masculinity testing to overcome anxiety about their sexual identities. Such anxiety is particularly acute among those who are denied adult opportunities to demonstrate such claims. These challenges involve attempts to physically intimidate others. The result is an increased likelihood of deviance (Tittle and Paternoster 2000). In one review of the features of the torturers, the role of the group in promoting masculinity as a form of power, emphasizing competition, dominance and control, continually emerges (Reyes-Quilodran 2001). The individuals who participated in Huggins's study also tended not to express compassion, caring, concern, or empathy with the victims. Peer group pressure is strongly correlated with male antisocial behavior (Zimring 1981; Akers 1985). Elliot and Menard (1996), Warr and Stafford (1991), and Monahan, Steinberg and Cauffman (2009) also find that peers who either encourage misbehavior or misbehave themselves also select friends and associates who misbehave. Based on these findings, one can argue that individual motivations coupled with group motivations can easily drive individuals to perpetrate criminal acts.

Minor (1980) and Sykes and Matza (1957) identify processes that undermine both social control and selfcontrol that are called "techniques of neutralization." These provide a cognitive mechanism that serves to release deviants from constraints. According to these authors, the techniques involved denial of responsibility, denial of the victim, denial of the injury, appeals to a higher loyalty ("I had to defend my mother's honor/the fatherland"), reliance on the metaphor of the ledger ("look at the good things we have done"), and condemning the condemners. The group helps the individual to reduce guilty feelings and to deny the magnitude of the damage caused. These techniques of neutralization help the individual to develop moral disengagement: "[The moral] disengagement may centre on redefining harmful conduct as honorable by moral justification, exonerating social comparison and sanitizing language. It may focus on agency of action so that perpetrators can minimize their role in causing harm by diffusion and displacement of responsibility. It may involve minimizing or distorting the harm that flows from detrimental actions; and the disengagement may include dehumanizing and blaming the victims of the maltreatment" (Bandura 2002: 102). The following strategies were used by Brazilian interviewees to explain and excuse atrocities: diffusing responsibility; blaming various individuals, whether victims or perpetrators; citing orders as a cause; and asserting that professionalism had correctly guided their and others' violence (Huggins Haritos-Fatouros and Zimbardo 2002: 192).

The tendency to undermine social control is also explained by the dynamics of authority. Kelman and Hamilton (1995) define the dynamics of authority as the legitimacy of the system, what the authority demands in a society, and the resulting communication between that authority and individuals in an organizational context. This definition is based on a structural model of the processes of social influence that includes compliance, identification, and internalization (Kelman 1961). Compliance refers to situations in which "an individual accepts influence from another person or group in the hope of achieving a favorable reaction, or avoiding an unfavorable reaction" (Kelman 1961: 104). Identification occurs when "an individual adopts behavior associated with a satisfactory self-defining relationship to another person or group" (Kelman 1961: 104). Self-definition involves a person's self-image and the relationship through which two persons or groups define their role with reference to the other. Interactions between members of a social group lead them to mirror one another, and this process defines the individual's behavioral pattern and personal identity (Scheier and Carver 1988). Internalization occurs when a person accepts the social influences to which s/he is exposed because they induce behavior congruent with his/her value system. These values reinforce the beliefs of the individual and are socially derived and shared. Values generate a set of personal standards that the person can use to decide whether to reject or accept the encouraged behavior. Acceptance of the behavior will depend on whether it is useful for solving a problem, fits within her/his worldview, is consistent with his/her moral convictions, and overemphasizes his/her values (auto-confirmation). The control held by social alliances over potential deviant behavior is based on the tendency of those people integrated into social networks to incorporate the norms or values of those groups into their own internal moral systems (Nye 1958; Braithwaite 1989; Felson 1986; Hirschi 2002; Farrington. 2011). Group pressures are able to persuade the individual to act against his own best judgment because his/her own judgment about reality is often colored by how other group members view it (Cialdini and Trost, 1989; Latane and Wolf 1981). 
The fear of negative consequences that are certain, severe and rapid produces conformity and that effect is enhanced when individuals' fears match those of the group (Tittle 1980). These factors may explain why Uruguayan agents (Calace 1988; García Rivas 1984) and Chilean (Henníngs, Uribe and Guajardo 1995) and Brazilian policemen reported that their work would be jeopardized by peers who were interested in their own concerns. In the Brazilian case, this fear was permanently instilled through the police socialization process, which encouraged policemen to be mistrustful of one another and of an ever-expanding set of dangerous others and which created a mindset in which everyone was a suspect.

Zimbardo (1970; 2008) conducts numerous studies to test the process of losing one's identity and becoming part of a group as a situational variable. One of the features of this process is deindividuation, which occurs through a complex chain of events. First, the presence of many other people encourages feelings of anonymity. Then, the individual feels that s/he loses her/his identity and becomes part of the group. Under these conditions, the individual can no longer be singled out and held responsible for his/her behavior. This feeling generates a loss of self-awareness, reduced concern regarding the evaluations of others, and a narrowed focus of attention. When these processes are combined, restraints lower on antisocial criminal behaviors. These processes are the basic ingredients of mass violence. For instance, Chilean military institutions included specialized units in charge of perpetrating torture (Rettig et al. 1991; Valech et al. 2004). The structure of the organization created instances in which each member was responsible for executing a specific task and unaware of other tasks simultaneously being performed by members of the same unit or of other units. In the Chilean report on the detention and final whereabouts of the victims who were disappeared, the agents indicated that they were unaware of the complete procedure followed to detain torture, kill and "disappear" victims.

A relevant aspect of deindividuation is that it is not a feature unique to mass behavior. The effect may be achieved through disguises, masks, or uniforms that are also worn by others. People tend to be more abusive, aggressive, and violent when their identities are hidden, and this tendency is reflected in contemporary soldiers, guerrillas and military advisers who are deindividuated by their uniforms (Zimbardo 1970; 2008). For instance, Brazilian group anonymity seems to have encouraged insularity within the elite squad, supporting police bonding, mutual dependence, and separation from outsiders (Huggins, HaritosFatouros and Zimbardo 2002: 185).

Human rights violations, especially among specific social groups and indigenous populations, were one of the gravest consequences of Latin American military interventions in politics. In the search for an explanation for military behavior and its relation to human rights abuses, such as torture, the structures, principles, and values created by the military apparatus and the mechanisms utilized to reproduce military patterns and training practices are the most commonly identified variables to explain these behaviors (e.g., Gibson and Haritos-Fatouros 1988; Haritos-Fatouros 2003; Kelman 1995; Kelman and Hamilton 1989; Zagorski 1992). The group dynamics that exist within military organizations are also closely related to these institutional variables because they encourage expected behaviors. Group structures, rituals, values, interaction dynamics, perceptions of the enemy, and identities can be reinforced by a threat (real or perceived) such that the group becomes able to define who is with them and who is against them (Calace 1988; Conroy 2000; Haritos-Fatouros 2003; Henníngs, Uribe and Guajardo 1995)

The purpose of this case study is to examine the extent to which group influences based on the relationship between the perpetrator and the victim affect an individual's willingness to commit acts of torture and to determine the mediating motivations.

\section{METHOD}

This research attempts to identify the group influences that motivate individuals in a military system and/or police associated with a military structure to engage in torture. It also describes the general context in which these acts occur. An additional objective of this case study is to identify the direct and indirect variables involved in the perpetration of acts of torture. Hence, this study focuses on the relationship between the perpetrator and the victim and probes the mediating motivations that affect individuals' willingness to commit acts of torture. The focus of this study is intelligence agents who worked in Chilean military and police institutions and units in which torture was conducted during the Chilean military regime (from 1973 to 1990). Some individuals who engaged in torture during the Chilean military regime remain active in the military or police system or receive retirement benefits from these institutions. Additionally, confessing 
publicly to having committed illegal acts could provoke legal prosecution of the perpetrators, and most perpetrators do not trust researchers to maintain confidentiality. In Chile, the military and police are closed groups that keep civilians separate from the military (Vargas 1997). These features encourage military personnel who did not perpetrate torture to avoid participation in any activity that could compromise them; therefore, no experimental designs can be used. Hence, one can access this group only through individuals who are serving prison sentences for killing civilians, and access to these prisoners must be authorized by prison authorities. Individual letters were written to the inmates to request voluntary participation in this study; six of twenty-three inmates contacted agreed to participate. None of the participants was affected by mental illness. The Institutional Review Board at Washington State University approved this study (05873-001), and its standards were used to conduct this research. The identity of each participant is protected, as guaranteed anonymity is a condition for participation in the study. Thus, the data do not provide the names of the participants, and they are kept under lock and key. All interviews were conducted in a private room.

The prisoners' files were reviewed, as were any associated psychological, social and/or forensic evaluation reports. This information guided the semistructured interviews and indicated whether any of the interviewees had a mental illness as a result of aging, in which case they were eliminated from the study.

The qualitative method used in this study allowed the researcher to discern meaning once immersed in the data (Neuman 2005). Because this is an exploratory study, data analysis was guided by the possibility of new and unexpected information. This type of research has not been conducted previously in Chile. Therefore, the application of the method had to be flexible to allow for the incorporation of new variables that could improve our understanding of the causes of torture in the studied group. Although the difficulty of obtaining a large sample obliged us to gather information from a small number of cases, we explored each case in great depth and in detail. Although the generalizability of the cases is limited (George and Bennett 2005), the qualitative method allows one to identify cases that are not common in the general population, such as torturers, and offers details about the elements that may influence this behavior (Yin 2011). The length of the interviews with the six subjects and the number of interviews with each subject made it possible to achieve saturation (Strauss and Corbin 2002).

When the Chilean coup occurred in 1973, each branch of the armed forces and police (the carabineers and the investigative police) had its own agency or division in charge of intelligence tasks. Although these agencies were part of the repressive military regime, most of them acted during different periods of the regime (from 1973 to 1990). The six interviewees belonged to three intelligence agencies: the CNI (Central de Informaciones, National Information Center, between 1977 and 1990), the DINE (Dirección de Inteligencia del Ejército, Army Intelligence Office) and the DICOMCAR (Dirección de Comunicaciones de Carabineros, Office of Carabineer Communications). The first two agencies were directly related to different parts of the army; the latter, to the police.

Two national reports were analyzed: The Report of the Committee on Truth and Reconciliation and the Report of the National Committee on Political Prison and Torture. Both reports describe the political violence and human rights violations perpetrated in Chile during the military regime. The detail in these reports was obtained from numerous interviews and testimonies provided by the victims and their families. The objective of these reports was to distinguish the facts from the interviewees' perceptions of the facts and to gain a deeper knowledge of these historical events.

The conduction of many in-depth interviews created an intimate familiarity with people's lives and cultures. This approach also made it possible to observe similarities and differences in behavioral patterns. Between five and seven semi-structured interviews were conducted with each participant, and depending on the results of the first, the second could be structured to reduce previous difficulties. Only one interviewer conducted the study. Each interview took approximately two hours. This choice made it possible to pinpoint the best time to conduct an interview and to reformulate questions, thereby reducing non-response. This method also facilitated attaining several measures and reduced bias.

The objective of the first and second interviews was to gain the interviewees' trust and generate rapport between the interviewee and interviewer. To achieve this objective, the interviews focused on general topics, such as family concerns, childhoods, and hobbies. During subsequent interviews, they were asked about their experiences with their judicial trial and 
incarceration. These topics allowed the interviewer to progress to questions about their jobs and their experiences with the intelligence agencies. The pace of the interviews was gradual, which allowed the interviewer to cover more complex issues, such as the perpetration of torture against their victims. The interviews used a set of semi-structured questions that helped the interviewer focus on the major issues in the data and employ a consistent method. However, the interviewer was able to obtain new information and reformulate questions. Other advantages of personal interviews include the ability to engage in multi-method data collection, which involves observations and visual cues. The use of observation offered general information about the interviewees and allowed the researcher to note their attitudes toward the interviews. Field notes were systematically written, and the interviewees remain anonymous (Ruiz-Olabuénaga and Ispizua 1989).

The data collected from in-depth interviews was triangulated with other sources of information: interviews with two prosecutors and judicial files. These sources of information were used to analyze the sentences imposed by the court. The objective was to observe the presence or absence of the expected variables and the occurrence of unexpected variables. This information was recorded using the same categories used in the individual interviews. The triangulation of data collected permits the identification of similarities and differences among the selected cases (Orlikowski 1993; Strauss and Corbin 1998). Triangulation is a way of ensuring comprehensive, reflexive analysis of the data. The data analysis requires that the individual interview contents and court records data be codified into concepts and that these concepts placed into categories (Wetherell, Tylor, and Yates 2001). Each interview was immediately transcribed and then analyzed (Strauss 1987; Strauss and Corbin 2002). A single researcher conducted the interviews, which allows for consistent recording of the data.

\section{RESULTS AND ANALYSIS OF RESULTS}

Several issues, which are discussed in turn, emerged from these interviews.

\section{The Role of Images and Perceptions of the Enemy}

The participants in this study recall strong and unequivocal images of their opponents as diabolical enemies. Military training informed the torturers' perceptions of the enemy. The enemy's leftist, threatening characteristics were described in detail, and the subjects accepted this stereotype. This perception was reinforced by other military personnel. The prescribed treatment of the enemy was ultimately expressed through the behavior of the trainees. Their beliefs about the enemy determined their "truth." According to Participant 1 , the army selected the most indoctrinated individuals: those who did not question orders, showed excellent discipline, and believed what the army said about the enemy.

To Participant 1, the world was divided into two groups, the good and the bad. He was unable to perceive other groups of people. Those who were against the military government were the bad guys, and he had to eliminate them; if he did not, they would kill him. He does not feel any remorse. Like other members of his group, he strongly believes that the guerrillas and Marxist groups are destructive in nature. Moreover, he argues that he knows the characteristics of the enemy very well. He prepared himself over a long period (about ten years), studying the nature and modus operandi of the guerrillas to be able to persecute them.

He also believed that the enemy wanted to corrupt society and its values. This danger threatened the entire nation, and the enemy was particularly dangerous because it was supported by the Soviet Union and Cuba. This is a classic manifestation of the enemy image and is dependent on the Cold War era (Cottam, 1994). Though he argued that rebellion must be fought with violence rather than ideology, he also stated that the use of excessive violence was unnecessary. He did not torture his victims to brainwash them; indeed, he believed that "if one subject was born a mirista, s/he would die a mirista" (miristas were members of an armed group that opposed the military government, militants from the Movimiento de Izquierda Revolucionaria, MIR. During the military regime, the MIR was considered a terrorist group).

The perception of the guerrillas as enemies of the state did not provoke many changes in how the carabineers treated prisoners. Participant 1 developed the belief that he and his team were doing the right thing. The army's beliefs, the team's beliefs and his own became one. In this view, criminal behavior was absolutely acceptable to the group and to him. The carabineers, especially Participants 3 and 4 also accepted the behaviors expected of them. Both of them 
were absolutely convinced of the threat that the enemy posed. They believed in the danger of Marxism, and those beliefs merged with the notions of the enemy that they learned in their training and absorbed from Participant 6.

Indeed, according to Participants 6 and 4, Participant 6 was appointed to the DICOMCAR because the agents did not understand the behavioral patterns of guerrillas very well. Participant 6 was assigned the role of inculcating a group worldview and behavioral norms toward enemies. Others in the DICOMCAR learned how to fight the guerrillas from Participant 6. In addition, guerrilla attacks against policemen generated a sense of the enemy as a real threat. Participant 6 was convinced that "the enemy would do the same that I could do to him."

Participant 6 argued, "the enemy is a subject who uses violence to achieve his objectives, so I can achieve my objectives by using violence too." To him, "it is impossible to perceive the enemy as a person because if I thought that way, I could not attack him or her." Thus, the enemy became an intangible force around which a large number of myths and fantasies were created. Gradually, the fabricated view of the enemy painted the guerrillas as objects. In fact, Participant 6 referred to the enemy as "the element," a clear example of how agents turned people into objects. He used the same term to refer to other people, including other prisoners, teams of professionals or friends.

The police wanted to curtail the actions of the enemy, regardless of the cost or implication for their own future or for that of the institution. For Participants $1,3,4$, and 6 , perceptions of the enemy appear to have been the main motivation for torturing them. According to Participants 3 and 4 , the enemy was not a political prisoner but a terrorist. These respondents perceived themselves as being engaged in a war against the people of the left wing who were, and are still, perceived as terrorists because they fought with arms and military maneuvers. Participant 4 also argued that the enemy did not maintain strong family relationships so that they could move easily from one home to another. In addition, the enemy was perceived as hiding among civilians, making them difficult to find.

Participant 3 claimed that these terrorists received training from Lebanon, Cuba and East Germany. Therefore, they were experts in the use of arms and war strategies. This participant said, "I was trained to go war, and if they sent me to war, I went to win." He also commented, "If society does not like the methods used in war, then society should not send me to war... If I do not kill the enemy, he will kill me."

\section{Social Identity and Military Socialization}

The subjects of this study identified strongly with the military government and its institutions. They perceived themselves as members of elite institutions whose mission was to save the country from the enemy, even if this meant instilling fear in the citizenry. They developed strong in-group identities as members of this elite force and maintained clear out-group boundaries that defined the enemy and any others who intentionally or unintentionally prevented them from performing their mission. These identities and methods were instilled through education provided by the military and police institutions. For some, socialization in the military began at an early age, thus reinforcing the power of institutional socialization: they knew little else.

Identification with the institutional culture occurs at two different levels: identification with particular institutions and identification with the intelligence agency. In their identification with institutions such as the army and the carabineers, these individuals developed a sense of belonging and agreement with institutional principles and values. The other level of identification created a bond among the participants and an attachment to the culture of the intelligence agency. At this level, torture was legitimate, and the agency, through the particular institutions discussed, provided the necessary conditions to perpetrate this type of crime. The individuals accepted the use of torture as a tool to fight the enemy and developed a group dynamic that both encouraged this type of conduct and involved them in the crime. Nevertheless, they did not express emotional attachment to the intelligence agency.

The study participants provided numerous examples of the impact of identity and socialization. The police group maintained one "absolute" truth: the enemy represented a danger whose actions they wanted to constrain. They were not concerned with the future costs of this tactic for them or the institution. This perception of the enemy, coupled with their identification with both the values of the institution and their particular group, made it very easy for them to identify the in-group and out-group members. The outgroup included the enemy and civil society; the 
difference was that society required protection from the enemy. The military and police felt that civil society did not confront violence the way they did because it was the intelligence agency's job to bear the brunt of the violence. The idea was that because civil society did not have weapons training and was not familiar with the nature of the enemy, civilians could not understand the methods used by intelligence agents to repress the enemy. Moral values reinforced their role. Four interviewees believed that they played a leading role in protecting both society and their institution. One of them recalled, "I believed that I was playing an important role in social change."

Participant 1 never thought that he would be charged or condemned for his crimes. He believed in heroism and in true love of his country. Therefore, he was convinced that his actions were correct and perceived himself as a savior. The carabineers were convinced that they had the opportunity to retaliate for the attacks that the enemies had perpetrated against them and that they could not fail the institution; they perceived this as their national duty. Indeed, Participant 4 said, "I would do it again, but I would take precautions [to make sure I would not get] caught."

Participant 6 compared the group dynamics within the military intelligence agency with those of the DICOMCAR and suggested that the people who worked in the military agency were more idealistic. They were strongly committed to their institutional mission and were prepared to sacrifice their lives for that mission. This level of commitment was consistent from the highest authorities to the lowest level. He did not observe this dynamic in the DICOMCAR; only some individuals showed this level of commitment.

Participant 1's description of his socialization into the military is particularly illustrative of the process. He was 14 years old when he joined the army, and he assumed the army's values as his own, including a notion of true love of country that encouraged him to protect his country from the enemy. In the army, he learned to trust the authorities, especially his leader (a general): "I believed what the head of the army said." $\mathrm{He}$ was unable to question Augusto Pinochet's arguments, noting, "if he said that the guerrillas could depose the military government, I just believed it." He was absolutely convinced that the military regime was the only way to govern the country and to prevent the nation from falling into communism.

He grew up in the army, and his military training gave him tools to defend his country from the enemy.
His easy acceptance of these ideas came from his army training. During the first stage, the army taught him about the features of the enemy and the dangers that the enemy posed for his society and his country. During the second stage, he received specific training on Marxist enemies of the state. The mechanisms that he used to defeat the enemy were illegal, but he was willing to use them because of the nature of the enemy and because the authorities shared these perceptions and encouraged him to believe in these concepts.

In training the carabineers and the civil police, criminals were depicted as antisocial individuals who threatened the security of society. Mistreating delinquents was common practice in most police stations. Indeed, the national reports established that the carabineers arrested detainees and then began to mistreat the victims. These actions were common among the police and were not perceived as torture. For example, beating prostitutes was a regular police practice, as Participant 4 reported.

In short, all of the interviewees, both army soldiers and carabineers, felt a sense of obligation to their institutions and felt that they were taking part in accomplishing a necessary mission. Three of them were disappointed in their institutions during their trials, and they perceived the institutional authorities as manipulative when they refused to support the claims of the indicted officers that the institution supported the use of torture. They felt that they really shared cultural values when engaging in torture. Participant 3 still feels strong ties to the institution. He claims, "My heart is green" (referring to the color of the police/carabineer uniform). Those in command ordered his retirement, hid information about the procedures he carried out and did not take responsibility for giving him orders, but he still shares the institution's values. Four interviewees shared this overall attitude even though the institution, as represented by its leaders (i.e., its generals), did not take responsibility for issuing the orders to use torture. The interviewees interpret this as a signal of the authorities' cowardice, but they do not believe that this attitude is reflective of the character of the institution itself.

Masculinity as a form of power: Part of the socialization process in the Chilean state's coercive machinery was the amplification of masculinity as a form of power. To Participant 1 and his team, a macho man drinks more, has more women, does not show weakness during a torture session and is aggressive. Participant 1's job allowed him to lead a group of men 
and handle considerable power, making decisions and creating different methods of investigating and interrogating prisoners. Therefore, he was able to decide who could live and who had to be killed.

When engaged in torture, Participant 3 said that he had to show the victims that he was experienced. Therefore, he had to be strong, and his objective was to break the victim. Like Participant 1 , he was in charge of a group of people and showing weakness was not an option. Their degree of control gave these individuals the opportunity to display their strength to both the group and their intended victims. Both the CNI agents and the police went out and got drunk to cope with their violent actions.

Participant 1 said that he had to be strong and that he did not reveal any weakness in difficult situations. His subordinates had expectations, and if he showed any sign of doubt, the group would question his authority. Likewise, he would not trust a subordinate who doubted his ability to accomplish his tasks. Even if they were unsure about committing a crime, they could not show doubts. In other words, they simulated courage when they did not actually feel it.

The group had a pyramidal organizational structure with a leader on top who could see the pressures acting on the group. This motivated him to show selfcontrol during violent attacks and during torture sessions. In this way, the leader showed his dominance and revealed no weakness, and his subordinates were encouraged to emulate his demeanor. Hence, both the group norms and its structure favored torture.

Thus far, it has been argued that Chilean torturers maintained strong enemy images or stereotypes of the opposition, showed contempt for the non-committed, and held strongly internalized norms about the coercive state machinery. This feature is discussed next.

\section{Authority Dynamics and Legitimized Torture}

The next pattern affecting the use of torture that is evident is the impact of authority. As discussed above, authority within the group can lead to involvement in extraordinary activities by group members, activities that often violate individual and societal values. The subjects in this study manifested many of these patterns. A particularly important pattern identified in studies of obedience to authority is the extent to which leaders authorize, either implicitly or explicitly, the use of tactics such as torture and murder (Kelman and
Hamilton 1989; Staub 1989). For the carabineers, the institution facilitated torture and allowed the use of these methods. Because the main objective of torture was to obtain information, it was legitimate. The objective was not to kill people but to obtain information as quickly as possible. Another objective was to increase fear and deter attacks by other guerrillas who went into hiding. Participant 1 led a group of people in the $\mathrm{CNI}$ and agreed with the methods used to fight the guerrillas. The torture sessions were framed as a method of obtaining information. Although he and his team engaged in some "excesses", no one was punished for them. They needed to obtain information as rapidly as possible, and torture was the method that they used to achieve this goal. In addition, they wanted to destroy the enemy physically and mentally, which was accomplished by torture.

For Participant 3, torture was a form of retaliation that used the enemy's own methods. Participant 6 believed that torture was intended not only to obtain information but also to break down the enemy, his/her family and his/her entire existence. Participant 6 also mentioned another element related to the legalization of crimes related to torture: he explained that the seriousness of crimes was established during a certain period. If a crime such as torture or illegal arrest was regularly perpetrated, this crime became the status quo, and each group member accepted the action. Then, when serious crimes, such as homicide, were committed, the balance was upset and a new equilibrium was established such that homicide then became accepted and normal. Participant 6 distinguished between the police and the military intelligence agencies, arguing that although it was inappropriate for the police to kill someone, such an action was not criminal in the military.

\section{Moral Disengagement}

The subjects demonstrated both moral disengagement from their actions and obedience to authority. They were aware of the nature of their actions, but they were not disturbed because these actions were deemed necessary to defeat the enemy and were approved by their superiors. Participant 5 , for example, said that he did not harbor hate toward political enemies or prisoners; he perceived his role to have been a part of his job. In retrospect, he realized that he committed atrocities but did not take responsibility for his actions; instead, he blamed his commanders. He alleged that he was obligated to commit these crimes, as he did not see alternatives at 
that time. Here, is possible to observe that the interviewees justify their actions by blaming the authorities. They explained that they were aware of what they were doing; however, when they faced consequences for their actions, particularly when facing trial, they used this explanation regardless of other instances in which they openly expressed their convictions about how to eliminate the enemy. A clear example of this is provided by Participant 4: he does not regret what he did but regrets being caught.

The first time that Participant 1 killed someone, he was stationed in the north of the country at an army barracks. He participated in the mass shooting of civilians. He claimed, "I did not feel anything when I killed them because they were the enemy and a danger to society. If I did not kill the enemy, the enemy could kill us." He did not question the methods he used to kill, and he did not show symptoms of posttraumatic stress. At the School of the Americas, he said, he learned about enemies of the state and the role of the Communist Party in the destruction of society. This training taught him about the dictatorship of the working class and the use of arms to achieve power. Moreover, he learned how to fight the enemy using torture techniques. Later, he was in charge of teaching these ideas and techniques to other soldiers. He explained his attitude about the type of military indoctrination that he received: its main objective was to protect the country from those who threatened national security.

\section{Remorse and Regret}

Participants commonly coped with violence by getting drunk and going out with their colleagues (other agents) to forget what had occurred after an episode of violence. Participant 1 did not question why he did these things; he simply accepted the facts.

According to Participant 1 , he would only feel shame if his sons found out about the crimes he committed At this moment, he believes that he is responsible for what he did. He does not feel guilty about his actions, but he sometimes questions having tortured relatives of the enemy. Nevertheless, this guilt does not cause him suffering. Nor did the other participants express remorse; rather, they acted in the same way as the $\mathrm{CNI}$ agents after violent episodes: they went out and got drunk. None of the carabineers interviewed expressed remorse for their criminal acts; indeed, they only regretted being in jail and being far from their families.

\section{Undermining External Control and Denial of Responsibility}

All of the interviewees displayed evidence various levels of denial. Participants $1,3,4,5$, and 6 admitted the crimes for which they had been imprisoned but denied other crimes, such as sexual assault and robbery. Detailed information about such crimes was obtained from court records and judicial files.

Participant 2 did not assume responsibility for any crimes, and he justified his conviction and prison sentence as the result of having been a group leader. He claimed that the DINE never engaged in illicit activities and that he was not aware of any illicit activities conducted by the $\mathrm{CNI}$. He believed that these are simply stories told to discredit the institutions. However, during his trial, it emerged that he had engaged in torture and had given direct orders to kill civilians. For him, denial allowed him to maintain that he is an honorable person; he does not want to be judged by his family or to betray the institution with which he was affiliated.

Participant 1 directly participated in numerous crimes and knew very well that this was his role. His role in other crimes, including armed confrontation between the guerrillas and intelligence agents, was more indirect. Moral disengagement for him was ambiguous because he was sometimes able to identify his crimes and assume responsibility. Even so, he did not assume responsibility for crimes involving sexual assault or robbery. Similarly, he justified his behavior by saying that he was following orders, decreasing his responsibility, and he maintained that the victims represented a danger to society.

The perpetrators were unable to explain sexual assault from the standpoint of their professed role as saviors or protectors of society. They perceived that they could act with absolute impunity, and they possessed a level of power during a torture session that allowed them to act freely.

Robbery was convenient. The absence of punishment and access to the victim's property provided an opportunity to take anything they wanted. The victims were perceived as enemies with no rights. Similar to sexual assault, robbery is unjustifiable if the perpetrator wants to play the role of savior, and for this reason, they denied their roles in robbery and sexual assault to avoid social sanctions, especially from their families. 


\section{Group Dynamics}

As mentioned above, the power of group dynamics to influence conformity to norms that violate normally accepted behaviors are important when considering the causes of systematic torture. Group pressures to behave in certain ways produce the perception of a lack of choice. Failure to conform to those pressures can produce fear of punishment and expulsion from the group. Indoctrination and socialization into the group typically involve isolation from other groups such as friends and family, as well as from the rest of society. This isolation enforces group norms and commitment, as attachment to others is gradually eliminated and prevents exposure to information that conflicts with group doctrine. The findings of this study confirm the presence of many group dynamics.

\section{Perception of Threats and a Lack of Choice}

During the coup, Participant 1 was housed in army barracks with soldiers and isolated from society. Therefore, when Pinochet talked about "Plan Z" in which Cubans and leftist members would destroy the country via armed attacks, the soldiers believed him. Participant 1 indicated that members of the military who had ideas that conflicted with Plan Z or with the army would be dismissed from the institution. In other words, the military system did not allow any degree of opposition to its anti-Marxist ideology. Participant 1 agreed completely with this ideology and never felt threatened by the military. Therefore, he was unable to justify his behavior as the result coercion. He felt free to leave the $\mathrm{CNI}$ at any time, and he felt that his subordinates had the same freedom. He worked in the $\mathrm{CNI}$ and did his job because he really believed in their method for combating the guerrillas.

Participant 1's participation in the $\mathrm{CNI}$ was completely voluntary. He argued that he never felt that his life or his family members' lives were threatened. He did not believe that a member of the military could have been forced to enroll in the intelligence unit. One of the lawyers for the prosecution agreed with this point, noting that during his work as a human rights defense lawyer, he did not recall any soldiers being assassinated by the army after expressing disagreement with military ideology. However, army dissidents were removed from the army: they were forced to retire or simply dismissed.

The police were inspired to stop attacks against the lives of their fellow policemen and engaged voluntarily in this task. Belonging to an intelligence agency gave them prestige, and they wanted to work on a team that protected its own. None of the interviewees reported having been forced to work for this agency. Participant 6 , who was a civilian, felt that the rewards he received were superior to the external threats. He betrayed his political party and worked for the intelligence agencies, which persecuted the members of that party. The agencies protected him from the people he had betrayed; indeed, he reported that the party authorities had issued orders to kill him (as a traitor).

As Participant 6 explained, if an agent wanted to avoid being associated with crimes, the best strategy was to avoid being informed. For example, if a unit (composed of four or five people) assassinated or tortured a person, individuals in any other unit would try to avoid being present if they did not want to be linked that incident. Of course, when a team conducted an operation, it was impossible not be involved, "you needed people around you to be involved in the crime. [But] if you were not the direct perpetrator of the crime, you would avoid being present at the scene of the crime so that you would not be involved with the crime." This explanation reveals a certain level of disingenuousness: the individual who perpetrated the crime avoided being punished by indirectly involving other group members, making them accomplices and forcing them to keep the incident secret. This strategy meant that during the trials, it was perfectly possible to establish who had committed particular crimes, especially homicides, and this explains the distant attitudes of other agents from the same intelligence agency who were not sanctioned by the court regarding the prisoners (i.e., by claiming that they did not visit them). Thus, the intimacy of the group appears to have been instrumental. Unlike the other participants, Participant 6 felt the group's influence in the sense that he did not believe he could say no. He was unable to perceive other alternatives, and when he was given an order, he felt that it was impossible to debate it. Participant 5 also argued that if he refused to commit a crime, his life and his family would have been threatened. Therefore, he simply followed orders and held the authorities responsible, despite having benefitted for participating in these crimes. However, Participant 3 argued that a policeman was not obligated to be a member of the DICOMCAR, nor were their families threatened. "If someone did not indicate agreement with the work team, he was removed and reassigned to another unit... because that guy was not useful." 
The judicial files reveal that the unit chief and the director of the DICOMCAR planned the assassinations of Communist Party members, and those who perpetrated the homicides did not know about the plan until the unit chief issued the order. Participant 6 , who was very close to the unit chief, explained that the chief determined which group would commit a murder. Two policemen had committed a robbery during a home invasion, and their participation in the robbery connected them to the group (Participant 5 was one of these). The two others were loyal to him, but one had been recently assigned to the unit. Thus, it was necessary to compel him to join the team. The chief did this by involving him in the perpetration of a crime, producing complicity with both the chief and the group.

Whether the participants perceived a choice varied, with some reporting that participation was voluntary and that they were absolutely committed to the job, whereas others perceived group pressures. The latter were ranked below the other interviewees (a civilian and a sub-official).

\section{Cohesion and Loyalty}

Group cohesion was produced by the group's daily common activities. In the CNI, as in other intelligence agencies, the agents spent long periods with their fellow group members; missions forced them to spend time away from home or outside their cities of residence. Participant 3 notes that they spent many hours together in cars. This experience generated informal relationships among the group members.

Participant 3 explained that the police academy training created groups of twenty students. Each cohort was enrolled in the same courses and lived in the same dorms. This closeness among students produced a strong sense of cohesion. Indeed, if one of them committed an error, the entire group was punished. Individuality was accepted, but group characteristics took precedence. The bonds between the group members generated complicity. Later, the same group dynamic was reproduced at the police stations, with the added connotations of masculinity. Taking this view, it is possible to observe the deindividuation of the group members. These individuals attended family parties, gave each other nicknames, and created close friendships that crossed into their personal lives. They became the godfathers of each other's children. The forty members of the DICOMCAR experienced the same dynamic. Among the carabineers, group loyalty would deter any single member from failing the group.
They felt a duty to support the people in command. Nevertheless, the sense of cohesion and loyalty was functional. That is, when participants were imprisoned, they received few visits from other agents. As Participant 3 said, "I feel like a prostitute; everyone is involved with her, but nobody admits it."

\section{Isolation}

Participant 1 perceived his isolation from the civilian world. Indeed, his close friends were all part of the CNI or the army. Although the army did not prohibit him from having relationships with civilians, Participant 1 felt closer to others in the military. The same experience occurred among the policemen. The institutional training that they received and the type of work that the intelligence agency demanded required them to spend long hours at their jobs. Nobody wanted to be involved in criminal behavior, although the offending agent wanted to involve other agents in crimes to strengthen his ties to them as fellow perpetrators. Moreover, it seemed that civilians were unable to understand the nature of the enemy, and consequently, they could not understand the importance of torture to defeating the enemy and protecting society from this threat.

\section{Commitment to Secrecy}

Participant 1 understood the need for secrecy in espionage. However, he was unable to explain why the army kept secrets. He thought that perhaps people were cowardly and were afraid to lose status and credibility among their families or society.

During the trials, the Director of the DINE called all officials and sub-officials who had participated either indirectly or directly in civilian homicide and asked them to remain silent on the issue. These exchanges were mentioned in the judicial files, and some soldiers confirmed the reason for the meeting. As Participant 1 noted, the soldiers knew that their actions were illegal and punishable by law. However, they believed in their ability to hide information and thought that they could avoid revealing who was responsible for the crimes. Thus, the question of why these participants did the things they did remain. According to Participant 1 and the other four interviewees, a few reasons are common to most of them.

First, they had the power to act outside the law, and their experience demonstrated that under the military regime, they would not be punished; on the contrary, 
they would be positively rewarded. Indeed, they received sentences only with the return of the democratic government in 1990. At that time, the army was no longer in power, and the executive branch appointed judges to identify the human rights violations that had occurred during the military regime. During the regime, however, they perpetrated crimes with absolute impunity. Second, the military believed that civilians were unable to understand the nature of the enemy and that agents should use nontraditional (i.e., illegal) methods to combat their enemies. On this basis, the agents placed both political leaders and those guerrillas who effectively fought the military regime using violence into the same category. Third, they used their power to eliminate their political adversaries, even though they recognized that these illegal methods would not have been appropriate for use by society. Of course, they concealed information about or evidence of these illegal activities.

Secrecy also played an instrumental role. Participants noted said that if an individual committed more crimes, his/her unit would increase the pressure to involve that person in other crimes in order to keep institutional secrets and maintain loyalty. This could explain why the same individuals from different agencies were involved in numerous trials. As a member of the investigative police who led the police investigations of human rights violations explained, the same group of perpetrators appeared in most of the trials.

Participant 5 highlighted that everyone in the institution knew what they were doing or had done but pretended to be ignorant. Moreover, Participant 3 declared that the entire police force was aware of DICOMCAR's activities and that even members of the junta knew about the intelligence agency's activities. Indeed, the police officers from any headquarters would call the intelligence agents when they arrested a suspect for a crime related to political matters to collaborate in the interrogation of the detainee. This was a regular procedure, and therefore, the members of the carabineers could not say that they did not know about the DICOMCAR's activities. According to police academy training, detention locations, procedures and interrogation methods (torture techniques) were to be kept secret. Naturally, carabineer leaders denied knowledge of these activities during the investigations and trials, that is, they adopted the same attitude as the military authorities.

Participant 2 denied knowledge of these crimes and argued that he was unaware of those perpetrated by the DINE when he was a department chief. Although it is evident that he was lying, his behavior can be explained by his "inability" to speak about any secret. Despite the fact that he was in prison, he said, "I strongly preserve my loyalty to the army." To him, loyalty included keeping secrets.

Another more complex function of secrecy is also evident: sharing a secret within a group generates complicity among the group members, which in turn fosters closeness. If one group member is not aware of the group's secrets, he is indirectly excluded. Thus, secrecy increases group cohesion, although it also involves the group members in a crime. To group members, this commitment seemed to be a drawback because it forced them to become accomplices. At the same time, being an accomplice forced each individual to maintain secrecy to avoid being accused of the crimes of others or having others reveals his own crimes.

\section{Group Structure}

The group structure was influenced by the army and police institutions, and each group had a leader who outranked or was more senior. This pattern reduced conflicts between groups because they respected the institutional norms associated with seniority.

Participant 4 led several police groups, each of which consisted of three or four men. He held regular meetings with the full group, but each group addressed specific, compartmentalized information to reduce the risks to the internal security of the institution.

Participant 4 defined himself as an obedient and disciplined policeman: he followed the institution's rules very closely. This type of attitude was inculcated by the institution, and he in turn indoctrinated his team. Control was a tool used to regulate the behavior of subordinates in their professional and personal lives. The institution had and has the power to investigate the policemen's families and social groups. The army possessed this same ability.

However, the chief's power was limited. For example, he could not participate in the selection of the DICOMCAR members, although he could ask for changes among the subordinates if they did not adhere to the requirements for obedience and discipline. According to Participant 4, subordinates also had some control over placement. Police officers were not forced to work in the DICOMCAR. On the contrary, if someone did not want to work in the agency, he could ask to be 
reassigned to another department. This was also true of $\mathrm{CNI}$ agents. This structure allowed proper control of subordinates, as they were all committed members of this group.

\section{Status and Prestige}

Participant 6 said that the crimes were defined to fit into a legal framework. A person who enjoyed prestige and credibility among the members of various groups would be appointed to present the legal framework to them. This individual could achieve a type of credibility by becoming an expert in obtaining information about and persecuting the enemy.

Participant 3 clarified that acts of violence were approved by the direct chief and the peer group. Participant 3 had a position of authority (he was a leader) in his group, so he was not permitted to display any weakness or doubt. He gave orders, and although his subordinates could offer suggestions, he made the final decisions.

According to Participant 1, a leader had to be trustworthy, and his subordinates had to do what he said. The leader had to be assertive when making decisions, and he could not commit errors. He needed a thorough understanding of the Marxist ideology and beliefs of the enemy, as he could use this knowledge to obtain more information from his enemy using torture, in turn gaining social recognition from his subordinates. Participant 1 said, "When you have the power to arrest and kill people, you believe that you are superior to other people, that you are more intelligent, and this excessive confidence in yourself motivates you to sometimes do stupid things. And you think that others are so stupid that they are unable to see what you are doing." This attitude of superiority was encouraged by the authorities, his job group and his friends, and his criminal conduct brought him a form of recognition from the group and the authorities.

\section{DISCUSSION}

Having reviewed several analytical elements, a general pattern emerges. To perpetrate torture, a group needed to possess certain characteristics. The general environment was determined mainly by police and military institutions. Both military training and the socialization offered by the police favored the isolation of individuals from society. These findings are very similar to those of Huggins et al. (2002). This isolation encouraged group cohesion and common beliefs, particularly as involved the image of the enemy.
Perceptions of the enemy are among the main variables used to explain criminal behavior. Such perceptions are reinforced and shared by the group, although they also represent the beliefs of the individuals involved. Indeed, most of the interviewees joined these intelligence agencies to fight the enemy. They shared beliefs, had a common understanding of the enemy, and confirmed as much to one another. During this process, the participants forgot the humanity of their adversaries, perceiving them and their families as evil. The subjects indicated that they felt genuinely threatened by the enemy and feared for their entire society. The participants in this study firmly believed that their opponent was a diabolical enemy not only determined to destroy Chile but also capable of it, as the enemy image literature explains.

The group's beliefs converged with the institutional and agency culture, which not only encouraged similar perceptions of the enemy but also provided the physical facilities necessary to torture them. The intelligence agencies offered financial support along with such facilities. In the group, the methods used to weaken or exterminate the enemy were positively reinforced by the group and by institutional authorities. If we isolate an individual in a context in which his partners and the institution encourage and approve violent behavior, we can explain his conduct. We can also see how the institution satisfied individual motivations. This finding raises the question of whether anyone could become a torturer, as some authors argue, or whether individual values and beliefs must be effectively combined with institutional and group dynamics to support this type of crime. Indeed, sharing beliefs allowed them to increase their cohesion. Viewing an external enemy as a threat helped the group to focus on exterminating that enemy and reduced differences or conflicts between group members. This dynamic created a level of cohesion that was instrumental. Today, these individuals are rejected by their groups; other members do not even visit them in jail. It may be that those who were not condemned do not want to be associated with these crimes now that are rejected by society or it may be that their loyalty encourages them to keep their crimes a secret. Once on trial, the participants revealed secrets to avoid charges. Essentially, the groups' secrets increased the participants' commitment to the crime and protected other group members from exposure to judicial or social punishment.

Group cohesion linked to secrets commits the subject to engaging in a crime. The relationship 
between these three variables (group cohesion, secrecy and commitment) created an appropriate context for committing torture: if a person wanted to be a part of the group, he had to share in the secret (the group at this level of analysis is a unit containing three to four members). Here, two group levels are observed: the first is the unit, and the second is the agency. The secret/commitment dynamic operated at the level of the unit. At this level, the secret is conditioned by the type of torture perpetrated: if a member of the group increased the seriousness of the crime, committing sexual offenses or murders, then other group members are also motivated to increase their severity because each is forcing the others to keep his secret by making them party to the crime. As a result, each subject is unable to talk about a specific act of torture because they committed the same crime. The secret encourages group cohesion. Secrets also operated at the agency level, although the objectives were different. The agency avoided knowing the details of the units' actions to avoid becoming involved in the crimes. However, they were accomplices regardless of their level of participation, which also encouraged secret keeping. Group cohesion is a variable that can explain torturer behavior. Thus, observing a role for secrets within group dynamics is an expected result.

If we focus on individual beliefs, we can see that these individuals not only shared the beliefs held by the group but also accepted group dynamics that favored the perpetration of torture. Moreover, they accepted torture as a way to defeat the enemy, that is, they subscribed to a set of beliefs about the use of torture. These beliefs are shared by peers. The institution also created a group structure that influences the occurrence of torture. These organizations created a command structure in which one individual headed each group, leading either the unit or the agency and issuing direct orders to the agency leader, who then relayed these orders to group subordinates. This system allowed the head of a unit or agency to control subordinates and made the group very efficient in accomplishing its objectives or missions. The structure of dominance and control by a unique authority figure was also replicated in the dynamics of torture.

The torturer perceived that his mission was to obtain information and defeat the enemy, and he had absolute power to achieve this goal. The torturer was able to dominate the victim and exert absolute control over his or her life. In this situation, torturing a victim was completely viable, and the torturer's personal motivations were openly expressed.
As suggested by Kiesler and Keisler (1969) and Tittle (1989), these findings show that the torturer wanted group approval and recognition. Hence, he was unable to show doubt about whether to torture a victim. Even if he was unsure, if he wanted the group's acceptance, he had to commit torture. Individual motivations were also necessary to perpetrate torture. The interviewees referred exclusively to the crimes for which they were convicted (homicides) and denied responsibility for common crimes, such as robbery or sexual assaults. None of the subjects was prosecuted for torture. Although they all knew perfectly well that they behaved illegally, they explained their conduct based on the historical moment and the features of the enemy. While they committed other crimes that they were unable to explain as part of this war, they simply deny these acts. This denial mechanism appears consistently across the interviewees, as it allowed them to avoid social condemnation and to retain their selfconcept and self-esteem.

All of these participants committed other crimes, but these were dismissed as "normal" activities. For example, Participant 2 committed bribery, but he was never legally prosecuted; thus, he diminished it as a normal act. The same tendency is observed among the policemen (Participants $3,4,5$ ), who referred to police brutality as normal. Indeed, none of them tried to hide this information. On the contrary, they mention it as routine, even though they were condemned for the use of unnecessary violence. They also display this tendency when referring to torture.

A "clandestine world" allowed these individuals to create certain interpretations of facts that were not necessarily accurate. However, once the perpetrators established certain facts as true, they began to believe their lies to confirm their beliefs. Violent guerilla attacks supported their fantasies, and actual facts increased their perception of the enemy as an imminent danger representing evil. Their beliefs and values provided a logical framework from which to perpetrate crimes. Therefore, it was very difficult for them to question their behavior; instead, they maintained their thinking, which prevented them from doubting either their conduct or their beliefs.

One unexpected element that emerged from this case study is the rigidity in thinking that prevented these participants from feeling remorse. Sometimes, they showed ambivalence: they vacillated between acknowledging their crimes and blaming either the context or the institution. This ambiguity was resolved 
by the excuse of having followed orders. That is, when the interviewer asked them about their careers, each of them communicated feelings of autonomy, notions about heroes and a sense of superiority. However, this perception of autonomy would imply that they are directly responsible for their crimes, while they avoid this responsibility and preserve their self-image by claiming that they followed orders. None of them acknowledged gaining satisfaction from torturing a person, but they did feel gratified by their jobs. Thus, it is observed that individual features motivated each of them to begin working for an intelligence agency. In fact, all of them, except Participants 5 and 6 (who were unsure), recalled volunteering to be involved with the intelligence agency. All received economic and psychological rewards and felt certain that those benefits were deserved. It is clear that each had individual motivations for working with the intelligence agency that corresponded to his or her personal needs. Financial rewards had an important impact on their conduct because these not only helped them economically but also provided an institutional signal that they had done a very good job. All of the participants were able to develop successful careers and achieve high rank. In Chile, a high economic standard of living confers prestige and power, and the participants were able to achieve those things. The subjects were not very different from one another in this aspect; they sought economic gain, prestige and power, and the intelligence agencies gave them these things. The differences raise questions about the meanings of their motivations. That is, each interviewee claimed to have played an important role in defending the country from the enemy. Participant 4 invoked the image of the hero, and Participants 1, 3, and 6 describe being an agent like James Bond involved in intelligence matters for the benefit of the nation. Participants 2, 5 and 6 believed that the institutions involved (the army and the carabineers) gave them the opportunity to improve their social and economic status, as did the intelligence agencies. All of them were adults when they enrolled in the intelligence agency and when they tortured.

One element examined above is the type of training used by the army to make soldiers more tolerant of the use of violence. When this variable is observed separately from the others, it does not explain why some soldiers or police perpetrate torture while others do not. However, when this variable is associated with the individuals' motivations, it explains why some participants were more easily convinced to torture. It is important to distinguish among the previously mentioned personal motivations, individual beliefs, and training that each participant received.

Each interviewee's perception of impunity was strong. There were no sanctions on some types of conduct, and it was clear that there were no limits on their behavior. Although the interviewees knew very well that they were behaving illegally, the torture dynamics gave them the opportunity to exceed normal limits on conduct and to perpetrate acts that were unjustified by being "at war." Significantly, the structure and goals of the intelligence agencies sheltered any individual who participated in deviant conduct. Therefore, this aspect must also be considered to be an element that might encourage involvement in this type of agency. It would be interesting to interview the families of the respondents to determine how the subjects behaved in an intimate setting. Most family members learned about the criminal acts that the participants perpetrated during their trials. Unfortunately, limits imposed by the prison authorities made it impossible to investigate this aspect.

\section{CONCLUSIONS}

This research has not been previously conducted in Chile. As the study findings suggest, torture is a complex crime requiring the presence of numerous variables. The indirect or direct presence of these variables is necessary for this crime to occur. Institutional features associated with the military or police do not, by themselves, trigger such conduct. However, they favored and encouraged the behavior. Evidence supporting obedience to authority does not emerge unequivocally. First, some interviewees claimed that they followed orders, but they simultaneously recognized feeling gratified by their jobs and having joined the intelligence agencies voluntarily. When they were asked whether they were able to refuse an order, they claimed that they could refuse to perpetrate a crime and that they acted as they did because they were absolutely convinced that it was right. This research shows that the institutional structure and the way it disseminated orders favored the perpetration of torture and other crimes. Nevertheless, it was also necessary to cultivate individuals who were able to torture. In this respect, individual motivations coupled with group dynamics effectively perpetrated torture.

Another important distinction revealed in this study was that these torturers did not identify themselves as 
such. Their social identities were related to the military, police or intelligence agencies but not to the role of "torturer." They were convinced that torture was a tool that they used to achieve their goal: exterminating the enemy, eliminating the threat, obtaining information, and punishing the enemy. As Zimbardo (2008) argues, the agencies and the political scenario present choices regarding the type of world that they create. Under these conditions, the function of the group was complex. It was insufficient for the individual to share the perception that the enemy posed a threat. Rather, the group also needed to understand torture as a mechanism through which to fight the enemy. This crime generated group dynamics that allowed them to escalate to the most brutal forms of torture, with the participants sworn to secrecy.

This study examines torture as a crime, and the results help determine the conditions under which these crimes are perpetrated and, as a result, how they can be prevented. Although we may not be able to prevent individuals from perpetrating this type of crime, the results reveal that conditions favorable to such crimes can be prevented. The contribution of this study is an examination of the perceptions of people who engaged in torture in a real setting for several years and who were able to maintain their group dynamics over a long period of time, despite the fact that finding a sample of torturers who are proud to talk about their crimes is quite difficult. Small sample sizes and case study limit the generalizability of the findings, as the cases depend on the precision with which the sample is defined; therefore, more research should be conducted to obtain more answers. An approach to the study of this type of crime must be developed to yield findings that could spur future study. This study hopes to encourage researchers to look for answers to prevent this crime, which produced tremendous social damage in Latin America.

\section{REFERENCES}

Akers, Ronald L. 1985. Deviant Behavior: A Social Learning Approach. $3^{\text {rd }}$ Ed. Belmont CA: Wadsworth.

Bandura, Albert. 2002. "Selective Moral Disengagement in the Exercise of Moral Agency." Journal of Moral Education 31 (2): 101-119. https://doi.org/10.1080/0305724022014322

Braithwaite, John. 1989. Crime, Shame and Reintegration. NY: Cambridge University Press. https://doi.org/10.1017/CBO9780511804618

Brown, Rupert. 2000. Group Processes. Oxford: Blackwell.

Calace, José. 1988. Quince Años en el Infierno. Uruguay, Montevideo: Túpac Amaru Editorial.

Cialdini, Robert. E. and Melanie R. Trost. 1989. Social Influences: Social Norms, Conformity and Compliance. Social
Problems18: 200-217.

Código de Procedimiento Penal. 1906. Código Procedimiento Penal Chileno de la república de Chile. Artículo 232.

Ley 19.696. 2000. Código Procesal Penal República de Chile. Artículo 93.

Conroy, John. 2000. Unspeakable Acts, Ordinary People: The Dynamics of Torture. New York: Alfred A. Knopf.

Coser, Lewis A. 1986. "The Functions of Social Conflict." In Political psychology edited by Margaret Hermann. CA: Jossey-Bass Publishers.

Cottam, Martha.1986a. Foreign Policy Decision Making: The Influence of Cognition. Boulder: Westview.

Cottam, Martha. 1994b. Images and Intervention: U. S. Policies in Latin America. Pittsburgh: University of Pittsburgh Press.

Cottam, Martha and Cottam, Richard. 2001. Nationalism and Politics: The Political Behavior of Nation States. Boulder: Lynne Reinner Press.

Cottam, Richard. 1977. Foreign Policy Motivation. Pittsburgh: University of Pittsburgh Press.

Cottam, Martha, Beth Dietz, Elena Mastors and Thomas Preston. 2010. Introduction to Political Psychology. New York: Psychology Press.

Davies, James C. 1973. "Aggression, Violence, Revolution and War." In Handbook of Political Psychology, edited by J. N. Knutson. CA: Jossey-Bass Publishers.

Elliot, Delbert. S. and Scott Menard. 1996. "Delinquent Friends and Delinquent Behavior: Temporal and Developmental Patterns." Pp. 28-67 in Delinquency and Crime, edited by David J. Hawkins. New York: Cambridge University Press.

Farrington, David. P. 2011. "Families and Crime." Pp. 130-157 in Crime and Public Policy in James Q. Wilson and Joan Petersilia. New York: oxford University Press.

Felson, Marcus. 1986. "Linking Criminal Choice, Routine Activities, Informal Control, and Criminal Outcomes." Pp.119-128 in The Reasoning Criminal, edited by Derek B. Cornishand and Ronald V. Clarke. New York: Springer-Verlag. https://doi.org/10.1007/978-1-4613-8625-4 8

García Rivas, Hugo. 1984. Hugo García Rivas: Memorias de un Extorturador. Eduardo Varela-Cid. Argentina: El Cid Editor.

Gibson, Janice T. and M. Haritos-Fatouros, Mika. 1986. "The Education of a Torturer." Psychology Today 20:50-58.

Glasser, Barney G. 1978. Theoretical Sensitivity. University of California San Francisco: Sociology Press.

Haslam, S. Alexander and Stephen Sreicher. 2007. "Identity Entrepreneurship and the Consequences of Identity Failure: The Dynamics of Leadership in the BBC Prison Study." Social Psychology Quarterly 70 (2): 125-147. https://doi.org/10.1177/019027250707000204

Haritos-Fatouros, Mika. 1988a. "The Official Torturer: A Learning Model for Obedience to the Authority of Violence." Journal of Applied Social Psychology 18:1107-1120. https://doi.org/10.1111/j.1559-1816.1988.tb01196.x

Haritos-Fatouros, Mika. 2003b. The Psychological Origins of Institutionalizated Torture. Routledge Research International Series in Social Psychology.

Henníngs, Erika, Viviana Uribe and Gabriel Guajardo. 1995. Informe, Detención y Destino Final de Detenidos Desaparecidos por la DINA (1974-1977): Un Estudio Preliminar. Informe elaborado para la Corporación Nacional de Reparación y Reconciliación en Chile.

Hirschi, Travis. 2002. Causes of Delinquency. Transaction Publishers. New Burnswick. New Jersey.

Huggins, Martha, Mika Haritos-Fatouros and Philip Zimbardo. 2002. Violence Workers: Police Torturers and Murders Reconstruct Brazilian Atrocities. CA: University of California Press. https://doi.org/10.1525/california/9780520234468.001.0001 
Kelman, Herbert C. 1995. "The Social Context of Torture: Policy Process and Authority of the Torturer." Pp. 21-38 in The Politics of Pain: Torturers and Their Masters, edited by Ronald D. Crelinsten, and Alex P. Schmid. San Francisco: Westview Press.

Kelman, Herbert C. 1961. "Processes of opinion change." Public Opinion Quarterly 25: $57-78$. https://doi.org/10.1086/266996

Kelman, Herbert C. and V. Lee Hamilton. 1989. Crime of Obedience: Toward a Social Psychology of Authority and Responsibility. New Haven: Yale University Press.

Kiesler, Charles A. and S. B. Kiesler. 1969. Conformity. Reading, MA: Addison-Wesley .

Latane, Bibb and Sharon Wolf. 1981. "The Social Impact of Majorities and Minorities." Psychological Review 88:483-453. https://doi.org/10.1037/0033-295X.88.5.438

Matza, David. 1964. Delinquency and Drift. New York: John Wiley.

Monahan, Kathryn C., Laurence Steinberg, and Elizabeth Cauffman. 2009. "Affiliation with Antisocial Peers, Susceptibility to Peer Influence, and Antisocial Behavior during the Transition to Adulthood." Developmental Psychology 45(6):1520-1530. https://doi.org/10.1037/a0017417

Neuman, W. Lawrance. 2005. Social Research Methods: Qualitative and Quantitative Approaches. $3^{\text {rd }}$ Edition. Allyn and Bacon.

Never Again. 1986. Nunca Más: Never Again: A Report by Argentina's National Commission on Disappeared People. Great Britain: Butter and Tanner Ltd. Frame, Somerset and London.

Minor, William. 1980. "The Neutralization of Criminal Offense." Criminology 18: 103-120. https://doi.org/10.1111/j.1745-9125.1980.tb01351.x

Nye, F. Ivan. 1958. Family Relationships and Delinquent Behavior. NY: John Wiley.

Orlikowski, Wanda J. 1993. "CASE Tools as Organizational Change: Investigating Incremental and Radical Changes in Systems Development." MIS Quarterly17 (3): 309-340. https://doi.org/10.2307/249774

Reicher, Stephen and Alexander S. Haslam. 2006. "Rethinking the Psychology of Tyranny: The BBC Prison Study." British Journal of Social Psychology 45:1-40. https://doi.org/10.1348/014466605X48998

Rettig, Raúl, Jaime Castillo, José Cea, Mónica Jiménez, Ricardo Martín, Laura Novoa, Gonzalo Vial and José Zalaquett. 1991. Informe de la Nacional Comisión de Verdad y Reconciliación. Gobierno de Chile.

Reyes-Quilodran, C. 2001. The main factors that motive to torture. Unpublished master's thesis. Washington State University.

Ruiz-Olabuénaga, José I. and Maria A. Ispizua. 1989. La Decodificación de la Vida Cotidiana: Métodos de Investigación Cualitativa. Bilbao: Universidad de Deusto.

Scheier, Michael and Charles Carver. 1988. "A Model of Behavioral Self-regulation: Translating Intention Into Action." Advances in Experimental Social Psychology 21: 303-346. https://doi.org/10.1016/S0065-2601(08)60230-0

Staub, Ervin. 1989. The Roots of Evil: Origins of Genocide and Other Group Violence. New York: Cambridge University Press.
Strauss, Anselm. 1987. Qualitative Analysis for Social Scientists. Cambridge University Press. https://doi.org/10.1017/CBO9780511557842

Strauss, Anselm and Juliet Corbin. 1998a. Basics of Qualitative Research. SAGE Publications, Inc.

Strauss, Anselm and Juliet Corbin. 2002b. Bases de la Investigación Cualitativa. Colombia: Universidad de Antioquia.

Sykes, Gresham and David Matza. 1957. "Techniques o Neutralization: A theory of Delinquency." American Sociological Review 22: 664-670. https://doi.org/10.2307/2089195

United Nations. 1974. Torture and Other Cruel, Inhuman or Degrading Treatment or Punishment in Relation to Detention and Imprisonment. General Assembly resolution 3218 (XXIX).

Uruguay, Nunca Más. 1992. Uruguay Nunca Más: Informe sobre Violación de Derechos Humanos $(1972-1985) .2^{\text {nd }}$ Edition. Servicio Paz y Justicia Uruguay.

Valech, Sergio, María Sepúlveda, Miguel Amunátegui, Luciano Fouillioux, José Gómez, Elizabeth Lira, Lucas Sierra and Álvaro Varela. 2004. Informe de la Comisión Nacional de Prisión Política y Tortura. Gobierno de Chile.

Vargas, Augusto. 1997. "Civil-Military Relations in a Democratic Framework." In Democracy in Latin America: Patterns and Cycles, edited by Roderic Ai Camp. $2^{\text {nd }}$ Edition. Scholarly Resources Inc.

Tittle, Charles. 1980. Sanctions and Social Deviance: The Question of Deterrence. New York: Praeger.

Tittle, Charles and Raymond Paternoster. 2000. Social Deviance and Crime: An Organizational and Theoretical Approach Roxbury Publishing Company.

Tunnell, Kenneth. 1993. Political Crime in Contemporary America: A Critical Approach. New York: Garland Publishing.

Warr, Mark and Mark Stafford. 1991. "The Influence of Delinquent Peers: What They Think or What They Do?" Criminology 29: 851-866. https://doi.org/10.1111/j.1745-9125.1991.tb01090.x

Wetherell, Margaret, Stephanie Tylor and Simeon Yates. 2001. Discourse as Data: A Guide for Analysis. London, England: Sage.

Yin, Robert K. 2011. Applications of Case Study Research. 3th Edition. Sage.

Zagorski, Paul W. 1992. Democracy vs. National Security: Civilmilitary Relations in Latin America. Lynne Rienner Publishers.

Zimbardo, Philip. 1970a. The Human Choice: Individuation, Reason, and Order versus Desindividuation, Impulse, and Chao. In Nebraska Symposium on Motion 1969, edited by William J. Arnold and David Levine.Lincoln, NE: University of Nebraska.

Zimbardo, Philip. 2008b. El Efecto Lucifer: El Porqué de la Maldad. Ediciones Paidós, S. A.

Zimring, Franklyn E. 1981. "Kids, Groups and Crime: Some Implications of a Well-known Secret." Journal of Criminal Law and Criminology 72: 867-885. https://doi.org/10.2307/1143269

\section{DOI: https://doi.org/10.6000/1929-4409.2018.07.15}

(c) 2018 Reyes-Quilodran and Cottam; Licensee Lifescience Global.

This is an open access article licensed under the terms of the Creative Commons Attribution Non-Commercial License (http://creativecommons.org/licenses/by-nc/3.0/) which permits unrestricted, non-commercial use, distribution and reproduction in any medium, provided the work is properly cited. 